\title{
高電気伝導度養液土耕における灌水頻度のコマツナへの影響
}

\author{
有水賢吾 ${ }^{1,2} \cdot$ 澁澤 栄 $^{3} \cdot$ 岩崎泰永 ${ }^{4 *}$ \\ ${ }^{1}$ 東京農工大学大学院連合農学研究科 183-8509 東京都府中市幸町 3-5-8 \\ 2 森林研究・整備機構森林総合研究所 305-8687 茨城県つくば市松の里 1 \\ ${ }^{3}$ 東京農工大学大学院農学研究院 183-8509 東京都府中市幸町 3-5-8 \\ ${ }^{4}$ 農業・食品産業技術総合研究機構野菜花き研究所 $305-8666$ 茨城県つくば市観音台 $3-1-1$
}

\section{Effects of Irrigation Frequency on Komatsuna under High Electrical Conductivity Fertigation}

\author{
Kengo USUI ${ }^{1,2}$, Sakae SHIBUSAWA ${ }^{3}$ and Yasunaga IWASAKI ${ }^{4 *}$ \\ ${ }^{1}$ United Graduate School of Agriculture, Tokyo University of Agriculture and Technology, \\ 3-5-8 Saiwai-cho, Fuchu, Tokyo 183-8509, Japan \\ ${ }^{2}$ Forest Research and Management Organization Forestry and Forest Products Research Institute, \\ 1 Matsunosato, Tsukuba, Ibaraki 305-8687, Japan \\ ${ }^{3}$ Tokyo University of Agriculture and Technology, 3-5-8 Saiwai-cho, Fuchu, Tokyo 183-8509, Japan \\ ${ }^{4}$ NARO Institute of Vegetable and Floriculture Science, 3-1-1 Kannondai, Tsukuba, Ibaraki 305-8666, Japan
}

\begin{abstract}
In order to utilize high EC water for fertigation, the effects of irrigation frequency, fertilizer concentration, salinity for Komatsuna (Brassica rapa var. perviridis) were investigated. We observed significant interactions between fertilizer concentration and salinity on the number of leaves and shoot fresh weight, and between salinity and irrigation frequency on root dry weight. We found that low fertilizer concentration increased leaf length and shoot fresh weight at the beginning of cultivation, whereas leaf length, shoot fresh weight, shoot dry weight, root dry weight decreased at the end of cultivation. Additionally, we found that salinity decreased leaf length, number of leaves, shoot fresh weight, leaf area, shoot dry weight, and root dry weight. High irrigation frequency increased leaf length and root dry weight. The average soil volumetric moisture content increased after adding salt in the high-fertilizer concentration plot. High fertilizer concentration increased the average soil moisture content on the low-frequency irrigation plot. Overall, the average soil volumetric moisture content was higher in the high-frequency irrigation plot than in the low-frequency irrigation plot. It is considered that the root area can be maintained in the wet state, which contributes to water-efficient cultivation. Growth analysis showed no significant interactions among all the parameters studied, but showed a clear trend in the relative growth rate (RGR), net assimilation rate (NAR), and leaf area rate (LAR) in each growth period. There were significant correlations between RGR and NAR and between RGR and LAR. Correlation between RGR and NAR was higher than that between RGR and LAR. It suggested that the changes in dry weight yield were due to the changes in photosynthetic rate.
\end{abstract}

2017 年 8 月 4 日受付

2017 年 11 月 30 日受理

*Corresponding author: Yasunaga Iwasaki

(iwasakiy@affrc.go.jp) 
Keywords: growth analysis, komatsuna, salinity, soil moisture content, water management

緒言

自然環境の保全が重要視される現在, 水利用の多くを占め る農業に対する節水需要が高まっている ${ }^{1)}$. 多くの場合農地 においては電気伝導度（EC）の低い水が必要とされている が，世界的には低 $\mathrm{EC}$ 水にアクセスできる地域は多くはなく, 高 $\mathrm{EC}$ 水の利用が急務である. 特に $\mathrm{NaCl}$ などの塩類を含む 高 $\mathrm{EC}$ の水を利用した場合には生育障害が容易に発生しう る. 地球規模で水利用効率の改善が求められている現在, これまで利用が困難であった高 $\mathrm{EC}$ 水を灌水に利用すること で, 灌溉用水が容易に確保できない地域でも灌水を行うこと が可能である. 加えて, 高 EC 水による塩類ストレスを付加す ることによって生長を促すという報告もあり ${ }^{2-4)}$, 高 EC 下水再 生水の灌水利用も検討されている ${ }^{5)}$.

そこで, 農業に扔ける水利用問題の解決と高品質作物生 産に向けて本研究では高 $\mathrm{EC}$ 水の灌水への適用を検討する.

高 $\mathrm{EC}$ 水によって生育障害が発生する理由は主に浸透圧 ストレスと作物への塩類吸収によるものであり ${ }^{6)}$, 浸透ストレス によって根への水・養分移動が阻害されることで生育障害が 発生する. そこで高 ECによる浸透ポテンシャルの影響を軽減 するために, 本研究では灌水回数を変化させ土壤の水ポテン シャルを低く保つことで作物への影響を低減させた.

Silberらは根域における一定の最適含水率を維持するた めに連続灌溉間の時間間隔を短縮することにより, 栄養分濃 度の変動を減少させることができ, これにより植物への利用率 を高め, 根域の下での浸出を減少させることができるとしてお $\eta^{7)}$, 多〈の研究に扔いて高頻度灌水による作物生育向上効 果が確認されている ${ }^{8-12)}$.

そこで本研究では高 $\mathrm{EC}$ 水の灌水利用のために植物に対 する害に関する栽培試験の供試作物であり ${ }^{13)}$, 栽培期間が 短〈浸透ポテンシャルの影響を把握しやすいコマツナを用いて 肥料抢よび塩類によって EC を上昇させた水を用いて灌水頻 度を変化させることによる作物生育に対する基礎的な知見を 得ることを目的とした。

\section{材料および方法}

\section{1. 栽培条件}

国立研究開発法人野菜花き研究所 (茨城県つくば市) 内のガラスハウスを用いて試験を実施した. 供試作物はコマ
ツナ（サカタのタネ）を使用し, 栽培期間は 2017 年 5 月 14 日から 2017 年 6 月 14 日とした. 空調制御は実施しなかっ た. 栽培期間中のハウス内の最高気温は $40.8^{\circ} \mathrm{C}$, 最低気温

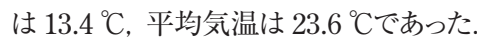

2017 年 5 月 14 日に 128 穴セルトレーに満たした培土（た ね培土 1 号, スミリン農産工業株式会社 ) に播種し, 初期成 育をそろえるために人工光閉鎖型苗生産装置苗テラス（三 菱樹脂アグリドリーム株式会社）で気温明期 $25{ }^{\circ} \mathrm{C} /$ 暗期 18 ${ }^{\circ} \mathrm{C}$, 明期時間 $16 \mathrm{~h}, \mathrm{CO}_{2}$ 濃度 $1000 \mathrm{ppm}$ で育苗した. 5 月 23 日にあらかじめ土壤を $5 \mathrm{~kg}$ 充填しておいたワグネルポット （1/5000 a）に各ポット 3 株ずつ定植した. 土壤吸着および 透水の時間遅れの影響を排除するため, 土壤は砂まじり砂 (礫分 $5.2 \%$, 砂分 $94.7 \%$, 細粒分 $0.1 \%$ ) を使用した. 定 植時に各ポット $250 \mathrm{~m} \ell$ ずつ水道水を灌水した. 施肥および 灌水は養液を用いて行った. 養液灌水はドリッパ $(\mathrm{PCJ}-$ LCNLドリッパ $2 \mathrm{~L} / \mathrm{H}$, ネタフィム) より灌水チューブ経由でポッ ト中心に対して行った.

塩類および肥料濃度は養液にて調整した. OATアグリオ $\mathrm{A}$ 処方 $1 / 2$ 単位および $1 / 4$ 単位に対し塩類 $(\mathrm{NaCl})$ 無添 加および 5000 ppm 添加区を設定した. 塩類濃度は Shaw の示す収量半減 EC を目標とした ${ }^{14)}$. 灌水回数は 1 回区と 5 回区とし, 1 回区は 1 日分の灌水量を毎日朝 6 時に, 5 回区 は 1 日の灌水量の $1 / 5$ 量を朝 6 時より 2 時間おきに分けて自 動灌水した. 各試験区は Table 1 のとおり設定し, 1 試験区 あたり 18 個体とした.

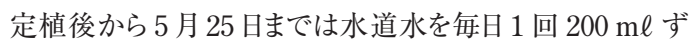
つ灌水し, その後 5 月 26 日より各試験区で養液灌水を行っ た. 1 日の灌水量は天候と成長量を考慮し 6 月 2 日まで 200 $\mathrm{m} \ell, 6$ 月 3 日に $300 \mathrm{~m} \ell, 6$ 月 4 日後 $400 \mathrm{~m} \ell$ とした. また, 栽 培期間中各試験区 1 ポットずつ排水量および EC を計測し

Table 1 Fertilizer concentration, salinity and irrigation frequency of each treatment.

\begin{tabular}{ccrc}
\hline \hline Treatment & $\begin{array}{c}\text { Fertilizer } \\
\text { concentration }\end{array}$ & $\begin{array}{c}\text { Salinity } \\
(\mathrm{ppm})\end{array}$ & $\begin{array}{c}\text { Irrigation } \\
\text { frequency }\left(\mathrm{d}^{-1}\right)\end{array}$ \\
\hline 1 & High & 0 & 1 \\
2 & High & 0 & 5 \\
3 & High & 5000 & 1 \\
4 & High & 5000 & 5 \\
5 & Low & 0 & 1 \\
6 & Low & 0 & 5 \\
7 & Low & 5000 & 1 \\
8 & Low & 5000 & 5 \\
\hline
\end{tabular}


た. 排水量はワグネルポット下部穴からの排水量をそれぞれ夕 ンクに貯め, 一定期間毎に質量を測定した. この際に排水 $\mathrm{EC}$ を電気伝導率計 $(\mathrm{CM}-31 \mathrm{P}$, 東带ディーケーケー)にて 計測した.

\section{2. 土蚺水分の計測}

各試験区 2 ポットずつドリッパ直下深さ $10 \mathrm{~cm}$ の位置に水 平方向に土䁃水分センサ (EC-5, Decagon Devices) を設置 した. 土壤水分は 5 月 23 日から 6 月 14 日まで 5 分間隔で計 測した. 各試験区 1 ポットずつポット中部涾さ $10 \mathrm{~cm}$ にポー ラスカップ受感部および圧力計 (AP-C 30 , キーエンス) から なるテンシオメー夕を設置し, 1 分ごとに土㗒水分ポテンシャル を観測した.

\section{3. 収穫調查}

各試験区は 6 ポットずつとし，成長の具合を見て 6 月 4 日， 6 月 8 日および 6 月 14 日にそれぞれ 2 ポットずつ解体調 查を実施し地上部新鮮重, 地上部乾物重, 地下部乾物重, 葉面積, 草丈, 葉数を測定した. 葉面積は葉面積計 $(\mathrm{Li}-$ $3100, \mathrm{LI}-\mathrm{COR})$ を用いて計測した. 乾物重は通風乾燥 $(80$ ${ }^{\circ} \mathrm{C}, 72 \mathrm{~h}$ )により求めた. 乾燥には恒温器 (JMB28DPN-S, カトー) を, 計測には電子天秤 $(\mathrm{FX}-$ 3000iWP, エーアンドデイ）を用いた。

\section{4. 成長解析および検定}

相対成長速度 (RGR, $\mathrm{g} \mathrm{g}^{-1} \mathrm{~d}^{-1}$ ), 純同化率 (NAR, $\mathrm{g}$ $\left.\mathrm{m}^{-2} \mathrm{~d}^{-1}\right)$ および葉面積比（LAR, $\mathrm{m}^{2} \mathrm{~g}^{-1}$ ) を以下の式によっ て算出した.

$$
\begin{aligned}
& R G R=\frac{\ln W_{2}-\ln W_{1}}{t_{2}-t_{1}} \\
& N A R=\frac{\left(\ln W_{2}-\ln W_{1}\right)\left(W_{2}-W_{1}\right)}{\left(t_{2}-t_{1}\right)\left(A_{2}-A_{1}\right)} \\
& L A R=\frac{A_{2}-A_{1}}{W_{2}-W_{1}}
\end{aligned}
$$

ここで, W は乾物重 $(\mathrm{g}), \mathrm{t}$ は日数 (d), A は葉面積 $\left(\mathrm{m}^{2}\right)$ を, 添え字は各計測時を表している. 各試験区の測定值につ いて解体調查ごとに三元配置分散分析を行った. 統計解析 にはR R.3.1を用いた ${ }^{15)}$.

\section{結果}

\section{1. 肥料濃度, 塩類および灌水頻度が及ぼす影響}

Table 2 にそれぞれの調查日における各試験区の平均地 上部新鮮重, 地上部乾物重, 地下部乾物重, 葉面積, 草 丈, 葉枚数, 生存株数, 枯死率を示す. Table 2 のうち 6 月 8日の草丈および葉面積が Bartlett 検定において $1 \%$ で有 意であったため Kruskal-Wallis 検定を, 他については三元 配置分散分析を行った. 三元配置分散分析の結果 6 月 8 日
の葉数, 地上部新鮮重, 6 月 14 日の地上部新鮮重において 肥料濃度と塩類の間に有意な交互作用があった. 主効果に ついては, 塩類は全期間を通じて有意であったものの, 肥料 濃度は 6 月 4 日の地上部新鮮重, 葉面積, 6 月 8 日の地下 部乾物重, 6 月 14 日の草丈, 地上部新鮮重, 地上部乾物 重, 地下部乾物重において, 灌水頻度は 6 月 4 日の草丈, 6 月 14 日の地下部乾物重においてのみ有意な効果が確認でき た. 主効果の傾向として, 肥料濃度について 6 月 8 日までは 低肥料濃度区で草丈と地上部新鮮重が大きくなる傾向にあっ たのに対して, 6 月 14 日では高肥料濃度区で草丈, 地上部 新鮮重, 地上部乾物重, 地下部乾物重が大きくなる傾向が あった. 塩類について全期間を通して無添加区で草丈, 葉 枚数, 地上部新鮮重, 葉面積, 地上部乾物重, 地下部乾物 重が大きくなる傾向にあった. 灌水頻度については高頻度灌 水区で草丈と地下部乾物重が大きくなる傾向にあった.

三元配置分散分析の結果交互作用が確認できたものにつ いては Tukey-Kramer 検定により多重比較を行った. 葉数 については肥料濃度が増加すると塩類添加・無添加の間に 差が確認でき, 塩類無添加の方が葉数は多かった. 地上部 新鮮重も同様に肥料濃度増加によって塩類添加・無添加の 間に顕著な差が観測でき, 塩類無添加区が重くなっていた. この傾向は 6 月 8 日および 6 月 14 日に共通して確認できた. 地下部乾物重については塩類無添加の場合には灌水頻度 増加によって地下部乾物重が増加傾向にあったのに対し, 塩 類添加区ではこれらの傾向は見られず, 灌水頻度増加による 有意な差は観測できなかった. Kruskal-Wallis 検定を実施 した項目については草丈, 葉面積両者に扔いて $1 \%$ 有意で あったが, Steel-Dwass 検定による多重比較を実施したとこ ろどの試験区間においても有意差は確認できなかった.

\section{2. 土壤水分推移}

栽培期間中の各試験区の土壤水分推移を Fig. 1 に示 す. Fig. 1aは 1, 2, 3, 5 区を, Fig. 1bは 1, 2, 4, 6 区の推移 をそれぞれ示している. 高肥料濃度区では塩分添加によって 平均体積含水率が増加し, 低頻度灌水区では高肥料濃度 区の方が平均含水率が高かった. 全体を通して低頻度灌水 区よりも高頻度灌水区の方が平均体積含水率が高く維持さ れており, 根域を湿潤状態で維持できていると考えられる. 排 水量および排液 EC の推移を Fig. 2 に示す. 排水量は明確 な傾向を観察できなかった. 排液 ECについては塩類添加区 および塩類無添加区でそれぞれ同様の傾向を示した（Fig. 2).

\section{3. 成長解析}

各試験区の RGR, NAR, LARを Table 3 に示す. 5 月 23 日 - 6 月 4 日の $\operatorname{NAR}(1 \%), \operatorname{LAR}(5 \%), 6$ 月4日 -6 月 8 日 の RGR (1\%), LAR (5\%), 6 月 8 日 -6月 14 日 の LAR 
Table 2 Effect of fertilizer concentration, salinity and irrigation frequency on growth of Komatsuna plant.

\begin{tabular}{|c|c|c|c|c|c|c|c|c|c|}
\hline & Treatment & $\begin{array}{l}\text { Leaf length } \\
\quad(\mathrm{mm})\end{array}$ & $\begin{array}{l}\text { Num. of } \\
\text { leaves }\end{array}$ & $\begin{array}{l}\text { Shoot } \\
\text { fresh } \\
\text { weight } \\
(\mathrm{g})\end{array}$ & $\begin{array}{l}\text { Leaf area } \\
\left(\mathrm{m}^{2}\right)\end{array}$ & $\begin{array}{l}\text { Shoot dry } \\
\text { weight } \\
(\mathrm{g})\end{array}$ & $\begin{array}{l}\text { Root dry } \\
\text { weight } \\
(\mathrm{g})\end{array}$ & $\begin{array}{c}\text { Num. of } \\
\text { alive plants }\end{array}$ & $\begin{array}{c}\text { Percentage } \\
\text { of dead } \\
\text { plants }(\%)\end{array}$ \\
\hline May 23 & - & - & - & 0.50 & 0.0012 & 0.05 & - & 10 & 0 \\
\hline \multirow[t]{8}{*}{ Jun 4} & 1 & 224 & 5 & 7.19 & 0.0161 & 0.68 & 0.06 & 6 & 0 \\
\hline & 2 & 237 & 5 & 8.42 & 0.0181 & 0.72 & 0.05 & 6 & 0 \\
\hline & 3 & 173 & 5 & 4.40 & 0.0115 & 0.42 & 0.04 & 6 & 0 \\
\hline & 4 & 189 & 5 & 5.09 & 0.0131 & 0.46 & 0.05 & 6 & 0 \\
\hline & 5 & 233 & 6 & 8.93 & 0.0218 & 0.77 & 0.05 & 6 & 0 \\
\hline & 6 & 243 & 6 & 8.64 & 0.0233 & 0.80 & 0.07 & 6 & 0 \\
\hline & 7 & 168 & 5 & 5.16 & 0.0121 & 0.41 & 0.03 & 5 & 16.7 \\
\hline & 8 & 192 & 5 & 6.63 & 0.0153 & 0.47 & 0.04 & 3 & 50.0 \\
\hline \multirow{7}{*}{ Significance $^{z}$} & $\mathrm{FC}^{\mathrm{y}}$ & ns & ns & $*$ & $* *$ & ns & ns & & \\
\hline & Salinity & $* *$ & $* *$ & $* *$ & $* *$ & $* *$ & $* *$ & & \\
\hline & If $^{\mathrm{x}}$ & $*$ & ns & ns & ns & ns & ns & & \\
\hline & $\mathrm{FC} \times$ Salinity & ns & ns & ns & ns & ns & ns & & \\
\hline & $\mathrm{FC} \times \mathrm{IF}$ & $\mathrm{ns}$ & ns & ns & ns & $\mathrm{ns}$ & ns & & \\
\hline & Salinity $\times$ IF & $\mathrm{ns}$ & ns & ns & ns & $\mathrm{ns}$ & ns & & \\
\hline & $\mathrm{FC} \times$ Salinity $\times \mathrm{IF}$ & ns & ns & ns & ns & ns & ns & & \\
\hline \multirow[t]{8}{*}{ Jun 8} & 1 & 337 & $8 a^{w}$ & $25.60 \mathrm{ab}$ & 0.0546 & 1.61 & $0.12 \mathrm{ab}$ & 6 & 0 \\
\hline & 2 & 345 & $8 \mathrm{a}$ & $30.78 \mathrm{~b}$ & 0.0625 & 1.82 & $0.14 \mathrm{ac}$ & 6 & 0 \\
\hline & 3 & 264 & $6 \mathrm{~b}$ & $13.69 \mathrm{ac}$ & 0.0302 & 1.05 & $0.08 \mathrm{ab}$ & 4 & 33.3 \\
\hline & 4 & 230 & $6 \mathrm{~b}$ & $12.44 \mathrm{c}$ & 0.0271 & 0.95 & $0.06 \mathrm{~b}$ & 6 & 0 \\
\hline & 5 & 305 & $7 \mathrm{ab}$ & $20.97 \mathrm{abc}$ & 0.0477 & 1.46 & $0.12 \mathrm{ac}$ & 6 & 0 \\
\hline & 6 & 325 & $8 \mathrm{a}$ & $24.63 \mathrm{ab}$ & 0.0517 & 1.63 & $0.18 \mathrm{c}$ & 6 & 0 \\
\hline & 7 & 229 & $7 \mathrm{ab}$ & $15.65 \mathrm{ac}$ & 0.0321 & 1.18 & $0.10 \mathrm{ab}$ & 6 & 0 \\
\hline & 8 & 260 & $7 \mathrm{ab}$ & $17.61 \mathrm{ac}$ & 0.0361 & 1.20 & $0.10 \mathrm{ab}$ & 6 & 0 \\
\hline \multirow[t]{7}{*}{ Significance } & $\mathrm{FC}$ & - & $\mathrm{ns}$ & ns & - & $\mathrm{ns}$ & $*$ & & \\
\hline & Salinity & - & $* *$ & $* *$ & - & $* *$ & $* *$ & & \\
\hline & IF & - & ns & ns & - & ns & ns & & \\
\hline & $\mathrm{FC} \times$ Salinity & - & $* *$ & $*$ & - & ns & ns & & \\
\hline & $\mathrm{FC} \times \mathrm{IF}$ & - & ns & ns & - & $\mathrm{ns}$ & ns & & \\
\hline & Salinity $\times$ IF & - & ns & ns & - & $\mathrm{ns}$ & $*$ & & \\
\hline & $\mathrm{FC} \times$ Salinity $\times \mathrm{IF}$ & - & ns & $\mathrm{ns}$ & - & $\mathrm{ns}$ & ns & & \\
\hline \multirow[t]{8}{*}{ Jun 14} & 1 & 410 & 10 & $58.33 \mathrm{ab}$ & 0.0964 & 3.79 & 0.12 & 6 & 0 \\
\hline & 2 & 424 & 10 & $62.68 \mathrm{~b}$ & 0.1038 & 4.19 & 0.27 & 6 & 0 \\
\hline & 3 & 277 & 8 & $27.80 \mathrm{c}$ & 0.0516 & 2.09 & 0.14 & 6 & 0 \\
\hline & 4 & 295 & 8 & $30.86 \mathrm{c}$ & 0.0603 & 2.39 & 0.18 & 5 & 16.7 \\
\hline & 5 & 367 & 10 & $38.52 \mathrm{ac}$ & 0.0792 & 2.91 & 0.26 & 6 & 0 \\
\hline & 6 & 367 & 9 & $38.72 \mathrm{ac}$ & 0.0793 & 3.00 & 0.40 & 6 & 0 \\
\hline & 7 & 268 & 7 & $21.79 \mathrm{c}$ & 0.0430 & 1.62 & 0.11 & 4 & 33.3 \\
\hline & 8 & 275 & 8 & $28.53 \mathrm{c}$ & 0.0558 & 2.24 & 0.22 & 6 & 0 \\
\hline \multirow{7}{*}{ Significance } & $\mathrm{FC}$ & $*$ & ns & $* *$ & ns & $*$ & $*$ & & \\
\hline & Salinity & $* *$ & $* *$ & $* *$ & $* *$ & $* *$ & $* *$ & & \\
\hline & IF & ns & ns & ns & ns & ns & $* *$ & & \\
\hline & $\mathrm{FC} \times$ Salinity & $\mathrm{ns}$ & ns & $*$ & ns & $\mathrm{ns}$ & ns & & \\
\hline & $\mathrm{FC} \times \mathrm{IF}$ & $\mathrm{ns}$ & ns & ns & ns & $\mathrm{ns}$ & ns & & \\
\hline & Salinity $\times I F$ & $\mathrm{~ns}$ & ns & ns & ns & $\mathrm{ns}$ & $\mathrm{ns}$ & & \\
\hline & $\mathrm{FC} \times$ Salinity $\times \mathrm{IF}$ & $\mathrm{ns}$ & ns & ns & ns & $\mathrm{ns}$ & ns & & \\
\hline
\end{tabular}

$\mathrm{z} *{ }^{* *}$ indicate significant at $\mathrm{P}<0.05$ and $\mathrm{P}<0.01$, respectively. ns indicates no significant.

${ }^{\mathrm{y}}$ Fertilizer concentration

${ }^{\mathrm{x}}$ Irrigation frequency

${ }^{\mathrm{w}}$ Different letters indicate significant differences at $\mathrm{P}<0.05$ 

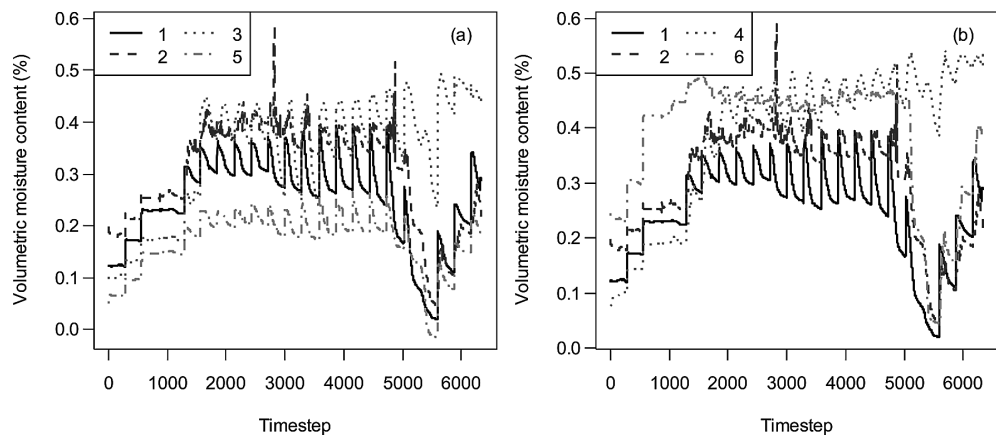

Fig. 1 Soil moisture changes in (a) Treatment 1, 2, 3, 5 (b) Treatment 1, 2, 4, 6. One timestep implies 5 minutes.
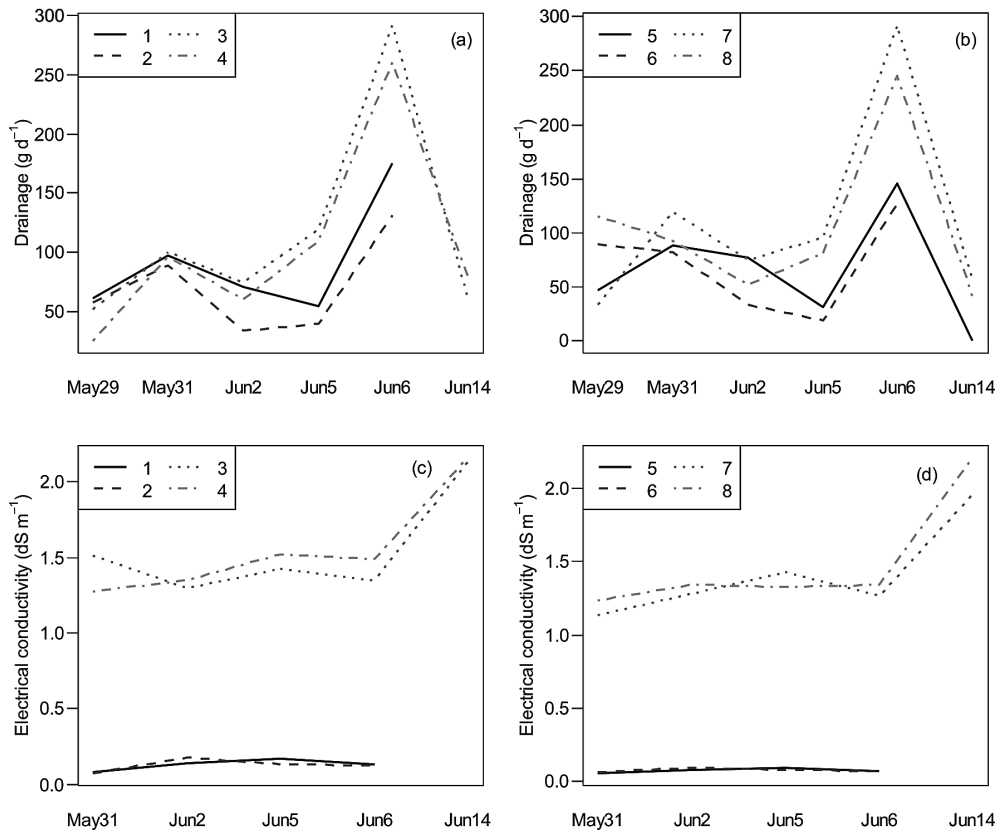

Fig. 2 Temporal changes in (a) amount of drainage from pots in treatment $1-4$, (b) treatment 5-8 and (c) electrical conductivity of drainage in treatment $1-4,(\mathrm{~d})$ treatment $5-8$.

（1％）においてはBartlett 検定が有意であったため,

Kruskal-Wallis 検定および Steel-Dwass 検定を行った.

三元配置分散分析の結果試験区間には交互作用は観測 できなかった. 主効果については 6 月 8 日-6月 14 日の RGR 以外に打いて塩類の, 6 月 8 日-6月 14 日の NARについて 肥料濃度の効果が有意に確認できた（Table 3)。それぞれ の主効果の傾向として, 塩類では RGR および 6 月 8 日 -6月 14 日の NAR は塩類無添加区の值が高い傾向にあったが, 6 月 4 日 -6 月 8 日の NAR は塩類添加区の值が高い傾向にあ った. 肥料濃度では高肥料濃度の值が高い傾向にあった。
Kruskal-Wallis 検定を実施した項目については 5 月 23 日 -6 月 4 日の NAR および LAR (1\%), 6 月 4 日 -6 月 8 日の LAR (1\%), 6月 8日-6月 14 日の LAR（1\%）については 有意差が確認できたが, Steel-Dwass 検定による多重比較 の結果どの試験区間でも有意差は確認できなかった. RGR は試験区ごとに特徵的な傾向は観測できないものの NARに ついては塩類添加によって 6 月 4 日-6月 8 日の間で上昇, その後低下した. LAR は反対に塩類添加によって 6 月 4 日 -6 月 8 日の間で低下, その後上昇した. RGRの変動に対す るNAR と LAR の関係を Fig. 3 に示す. ピアソン相関におけ 

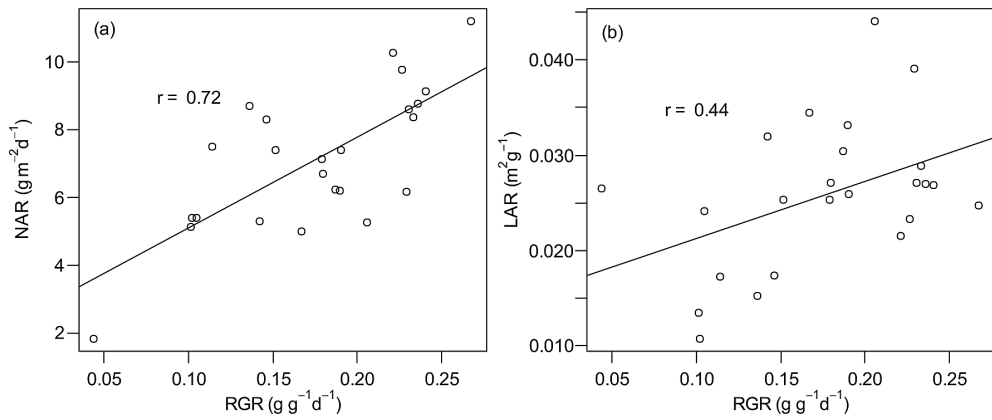

Fig. 3 Relationship between RGR and NAR (a), and RGR and LAR (b). $r$ implies correlation coefficient of the parameters.

る無相関検定の結果 RGR と NAR, LAR の間にはそれぞれ 有意水準 $1 \%$ 抢よ゙ $5 \%$ で有意な相関が認められた ${ }^{16)}$.

\section{考察}

肥料については茨城県の慣行の施肥設計が元肥 12-12-

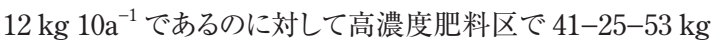
$10 \mathrm{a}^{-1}$, 低濃度肥料区で $21-12-26 \mathrm{~kg} 10 \mathrm{a}^{-1}$ 相当の肥料を投 入している.したがって, 本試験では慣行から慣行の 2 倍程 度の肥料を投入しており，養液土耕においては養分利用効 率の上昇が報告されているため肥料分の不足はないと考えら れる.

本研究では塩類添加による成長促進効果は観測できなか った. 桝田らはホウレンソウにおいて $\mathrm{NaCl}$ を添加した際に $200 \mathrm{ppm}$ において最も生育が良好であると報告している ${ }^{2)}$. 清水らは養液栽培に $\mathrm{NaCl}$ 添加による高品質化を試験してい

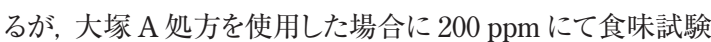
を含めた品質向上に及ぼす効果が高いとしている. 同時に地 上部中および地下部重に関しては $100 \mathrm{ppm}$ で効果が出てい るとしている ${ }^{17)}$. 本試験ではさらに高濃度の養液を生育期間 を通じて灌水しており, 継続的な塩類ストレスが生育に影響を 及ぼしいる可能性がある. 留森はホウレンソウ 13 品種にて 希釈海水（全塩類濃度 $0,1000,2000,5000 \mathrm{ppm}$ ）を灌水し た際の影響を調查しており, $1000 \mathrm{ppm}$ 区の生葉重は有意に 高く, $5000 \mathrm{ppm}$ 区では塩分無添加区に対し 50 \% と低かった と報告している ${ }^{18)}$. 本試験では塩類添加区の生体重は塩類 無添加区に比べて 60 \% となっており比較的一致した傾向に あった. 江波戸らは高塩類堆肥を用いたコマツナ連作栽培へ の影響を調查し, 1-3 作目については高塩類堆肥区の方が 地上部乾物重が多い傾向にあると報告している ${ }^{19)}$.

また, 灌水回数についても先行研究では高頻度灌水によっ て収量増加があるとされている. 吉田らはトマトにおける灌水 頻度および肥料濃度の影響を調査しており, マトリックポテンシ
ヤル $-6.3 \mathrm{kPa}$ 以下で $50 \mathrm{~m} \ell$ 灌水を行うことで草勢維持执よ び収量が増加したと報告している ${ }^{8)}$. Cook らは同様に, 窒素 施肥の頻度増加によって大果执よび全体の収量が増加したと 報告している ${ }^{11)}$. 湖東らはアルファルファについて灌水頻度が 蒸散速度や成長に及ほすす影響について気象因子も含め調査 しており, 特に高温期において灌水頻度が蒸散速度に与える 差が大きく, 高頻度灌水区は低頻度灌水区より $10 \%$ 収量が 高いことを報告している ${ }^{12}$. 本試験では 6 月 4 日拉よび 6 月 14 日の草丈および地下部乾物重においてこれらの傾向が観 測できたが，6月 8 日の塩類添加区における地下部乾物重 は, 低頻度灌水々同等もしくは低頻度灌水より低い值であっ た. 灌水頻度の増加による生育促進の要因として, 吉田らは 根周辺の水分移動による養分吸収促進, 根表面の肥料成分 濃度の上昇を, 安らは根の単位表面積に供給される酸素分 子あるいは無機イオン量の増大を挙げている ${ }^{8,20)}$. 池田らによ ると根域の水分移動が少なくなった場合に根表面に低無機 要素濃度層が形成されるとの報告があり ${ }^{21)}$, 根の周囲での 頻繁な水移動によって生育促進効果が見込まれる. 本研究 では高灌水頻度での草丈および地下部乾物重の増加が確 認できたが, これは根表面の低無機要素濃度層の破壊が理 由の一つとして考えられる. また, 灌水頻度増加による根への 水分供給回数の増加により, 根表面の無機イオン接触回数も 増加していると考えられ, 高灌水頻度での草丈および地下部 乾物重増加の一因になっていると推察される. 一方, 吉田ら が挙げた根表面の肥料濃度上昇については一定濃度の培 養液を灌水していることから発生していないと考えられ ${ }^{8)}$, こ れが先行研究に比べて灌水頻度の効果が明確に出なかった 原因の一つと考えられる.

本研究では灌水頻度が高いと平均体積含水率が高くなる 傾向にあった. 荒木は灌水開始土㙵圧力と1回あたりの灌水 量の変化によって湿潤土層の深さに及ぼす影響について報 告しており, 灌水量が少ない場合水分が地表付近に分布し, 灌水量が多い場合より下層まで分布すると報告している ${ }^{22)}$. 
Table 3 Results of RGR, NAR and LAR in each treatment.

\begin{tabular}{|c|c|c|c|c|}
\hline & Treatment & $\begin{array}{c}\text { RGR } \\
\left(\mathrm{g} \mathrm{g}^{-1} \mathrm{~d}^{-1}\right)\end{array}$ & $\begin{array}{c}\text { NAR } \\
\left(\mathrm{g} \mathrm{m}^{-2} \mathrm{~d}^{-1}\right)\end{array}$ & $\begin{array}{c}\text { LAR } \\
\left(\mathrm{m}^{2} \mathrm{~g}^{-1}\right)\end{array}$ \\
\hline \multirow[t]{8}{*}{ May23-Jun4 } & 1 & 0.22 & 10.2 & 0.022 \\
\hline & 2 & 0.23 & 9.8 & 0.023 \\
\hline & 3 & 0.18 & 7.1 & 0.025 \\
\hline & 4 & 0.19 & 7.4 & 0.026 \\
\hline & 5 & 0.23 & 8.6 & 0.027 \\
\hline & 6 & 0.24 & 8.8 & 0.027 \\
\hline & 7 & 0.18 & 6.7 & 0.027 \\
\hline & 8 & 0.19 & 6.2 & 0.033 \\
\hline \multirow[t]{7}{*}{ Significance $^{z}$} & $\mathrm{FC}^{\mathrm{y}}$ & $\mathrm{ns}$ & - & \\
\hline & Salinity & $* *$ & - & - \\
\hline & If $^{\mathrm{x}}$ & $\mathrm{ns}$ & - & - \\
\hline & $\mathrm{FC} \times$ Salinity & ns & - & - \\
\hline & $\mathrm{FC} \times \mathrm{IF}$ & $\mathrm{ns}$ & - & - \\
\hline & Salinity $\times$ IF & $\mathrm{ns}$ & - & - \\
\hline & $\begin{array}{l}\mathrm{FC} \times \text { Salinity } \\
\times \mathrm{IF}\end{array}$ & ns & - & - \\
\hline \multirow[t]{8}{*}{ Jun4-Jun8 } & 1 & 0.21 & 5.3 & 0.044 \\
\hline & 2 & 0.23 & 6.2 & 0.039 \\
\hline & 3 & 0.23 & 8.4 & 0.029 \\
\hline & 4 & 0.14 & 5.3 & 0.032 \\
\hline & 5 & 0.17 & 5.0 & 0.034 \\
\hline & 6 & 0.19 & 6.2 & 0.030 \\
\hline & 7 & 0.27 & 11.2 & 0.025 \\
\hline & 8 & 0.24 & 9.1 & 0.027 \\
\hline \multirow[t]{7}{*}{ Significance } & $\mathrm{FC}$ & - & $\mathrm{ns}$ & - \\
\hline & Salinity & - & $* *$ & - \\
\hline & If & - & $\mathrm{ns}$ & - \\
\hline & $\mathrm{FC} \times$ Salinity & - & ns & - \\
\hline & $\mathrm{FC} \times \mathrm{IF}$ & - & ns & - \\
\hline & Salinity $\times$ IF & - & ns & - \\
\hline & $\begin{array}{l}\text { FC } \times \text { Salinity } \\
\times \mathrm{IF}\end{array}$ & - & ns & - \\
\hline \multirow[t]{8}{*}{ Jun8-Jun14 } & 1 & 0.15 & 8.3 & 0.017 \\
\hline & 2 & 0.14 & 8.7 & 0.015 \\
\hline & 3 & 0.10 & 5.4 & 0.024 \\
\hline & 4 & 0.15 & 7.4 & 0.025 \\
\hline & 5 & 0.11 & 7.5 & 0.017 \\
\hline & 6 & 0.10 & 5.1 & 0.013 \\
\hline & 7 & 0.04 & 1.8 & 0.026 \\
\hline & 8 & 0.10 & 5.4 & 0.011 \\
\hline \multirow[t]{7}{*}{ Significance } & $\mathrm{FC}$ & $\mathrm{ns}$ & $*$ & - \\
\hline & Salinity & ns & $*$ & - \\
\hline & If & ns & ns & - \\
\hline & $\mathrm{FC} \times$ Salinity & ns & ns & - \\
\hline & $\mathrm{FC} \times \mathrm{IF}$ & ns & ns & - \\
\hline & Salinity $\times$ IF & ns & ns & - \\
\hline & $\begin{array}{l}\mathrm{FC} \times \text { Salinity } \\
\times \mathrm{IF}\end{array}$ & ns & ns & - \\
\hline
\end{tabular}

\footnotetext{
$\overline{\mathrm{z} *},{ }^{* *}$ indicate significant at $\mathrm{P}<0.05$ and $\mathrm{P}<0.01$, respectively. ns indicates no significant.

${ }^{\mathrm{y}}$ Fertilizer concentration

${ }^{\mathrm{x}}$ Irrigation frequency
}

吉田らも同様に灌水量が少なく灌水頻度が多いほど水分が 地表近くに分布し湿潤域が小さくなる傾向がみられた, と報告 している ${ }^{8)}$. 本研究では灌水量を同一にしていること, ポッ下 端を自由排水としていることから低頻度多量灌水時に灌水点 とポット下端の土壤水ポテンシャル差が大きくなり, きわめて迅 速に排水がなされたと考えられる. 高頻度少量灌水時にはポ テンシャル差が比較的小さいため, ポット内の水分滞留時間 が長く, 体積含水率が高くなると推察され, これらの報告と一 致する結果が得られた. よって, 高頻度灌水は下層への浸透 を抑制できる点から節水に効果があると考えられる. Fig. 2で 示した排水量は日積算日射量と相関傾向がみられ $(\mathrm{r}=$ -0.57), 日射量の変化によって光合成量が変化することで 作物の吸水量が変化していると推測される. また, 排水 $\mathrm{EC}$ はおおおね変動が少なく推移していたが, 塩類添加区が栽 培末期に上昇する傾向があった. 本試験では作物生育に合 わせて過不足なく灌水量を変化させていたが, 栽培末期にの み一時的に灌水量が不足する状態となったため, 結果的に $\mathrm{EC}$ 濃度の上昇につながったと考えられる。

成長解析の結果を踏まえると, RGR と NAR および LAR の 間には有意な正の相関が確認でき, かつ NARの相関係数 はLARに比べ高かった. よって RGRの変化への寄与は NAR の方が高いと考元れれ, 本研究における乾物生産速度 の変化は主に光合成速度の変化によるものと推察される.こ れは, 塩類ストレスにより NARが低下するというこれまでの知 見と一致する ${ }^{23)}$.

以上のように, 高 $\mathrm{EC}$ 水の灌水への利用を目指した基礎的 知見として, コマツナにおいて $\mathrm{NaCl}$ による塩類ストレス影響 が大きく確認できること, 灌水頻度増加による地下部乾物重 向上効果が見込めるものの塩類ストレスによる影響を抑える 程度の影響は見られないことを示した. 本試験内では高 EC 水を灌水に用いた際の基礎的知見を得たが，今後はこれら の影響を抑制する手法の提案が必要であると考兄られる.

\section{摘 要}

高 $\mathrm{EC}$ 水の養液土耕への利用のために灌水頻度, 肥料 濃度, 塩類を変化させてコマツナを栽培し影響を把握した。 葉数および地上部新鮮重に対し肥料濃度と塩類の交互作 用, 地下部乾物重について塩類と灌水頻度の交互作用を確 認した. 主効果の傾向として, 肥料濃度について栽培期間 初期に低肥料濃度区で草丈と地上部新鮮重が大きくなる傾 向にあったのに対して, 未期には高肥料濃度区で草丈, 地 上部新鮮重, 地上部乾物重, 地下部乾物重が大きくなる傾 向があった. 塩類について全期間を通して無添加区で草丈, 葉枚数, 地上部新鮮重, 葉面積, 地上部乾物重, 地下部乾 
物重が大きくなる傾向にあった. 灌水頻度については高頻度 灌水区で草丈と地下部乾物重が大きくなる傾向にあった. 栽 培期間中の各試験区の土㙵水分推移は高肥料濃度区では 塩分添加によって平均体積含水率が増加し, 低頻度灌水区 では高肥料濃度区の方が平均含水率が高かった. 全体を通 して低頻度灌水区よりも高頻度灌水区の方が平均体積含水 率は高く維持されており, 根域を湿潤状態で維持できていると 考えられ, 節水に効果があると推察される. 成長解析の結果, 各期間の RGR, NAR, LAR において交互作用は確認できず, 明確な傾向は見られなかった. RGR と NAR, LAR の間には それ有意な相関が認められた. よって RGRの変化への寄与 はNARの方が高いと考えられ, 本研究における乾物生産速 度の変化は主に光合成速度の変化によるものと推察された。

\section{謝 辞}

本研究の一部は「平成 29 年度国際共同研究パイロット 委託事業（イスラエルとの共同公募に基づく共同研究分 野)」「水質の異なる再生水の農業利用における処理, 利用 および影響に関する研究」において実施した. 本研究を進め るに当たり, 農業・食品産業技術総合研究機構野菜生産シ ステム研究領域の皆様に情報提供や助言を頂いた. ここに記 して関係各位に謝意を表す。

\section{引用文献}

1) FAO. The State of the World's Land and Water Resources for Food and Agriculture (SOLAW). -Managing systems at risk. The Food and Agriculture Organization of the United Nations, Rome and Earthscan, London. 1-285. 2011.

2) 桝田正治, 野村眞史. 水耕培養液への $\mathrm{NaCl}$ 添加によ る人工光下ホウレンソウの生育促進. 植物工場学会誌. 9: 29-35. 1997.

3) 三村聡, 星岳彦, 高辻正基. 塩化ナトリウム添加養液に よる養液栽培ホウレンソウの成育促進. 植物工場学会 誌. 7: 151-155. 1995.

4) 磯部勝孝, 荻島恵梨, 佐藤竜司, 杉山光, 肥後昌男, 鳥越洋一. キノアの発芽と初期生育における耐塩性の 品種間差と作物間差. 日本作物学会紀事. 83: 9-14. 2014.

5）重松賢行, 吉田綾子, 山下尚之, 田中宏明. 畑地灌溉 を想定した下水再生水の水質評価. EICA. 13: 109115. 2008.

6) Munns R, Tester M. Mechanisms of salinity tolerance. Annu. Rev. Plant Biol. 59: 651-681. 2008.

7) Silber A, Xu G, Levkovitch I, Soriano S, Bilu A, Wallach R. High fertigation frequency: the effects on uptake of nutrients, water and plant growth. Plant
Soil. 253: 467-477. 2003.

8）吉田千恵, 岩崎泰永, 牧野周, 池田英男. 養液土耕に おける灌水管理の違いがトマトの生育および収量に及ぼ す影響. 園芸学研究. 10: 325-331. 2011.

9）上山啓一, 小野寺康子, 大沼康. 夏秋卜マ卜の養液土 耕栽培における栄養診断に基づいた養水分管理方法. 宮城県農業・園芸総合研究所研究報告. 41-47. 2004.

10) $\mathrm{Xu} \mathrm{G,} \mathrm{Levkovitch} \mathrm{I,} \mathrm{Soriano} \mathrm{S,} \mathrm{Wallach} \mathrm{R,} \mathrm{Silber} \mathrm{A.}$ Integrated effect of irrigation frequency and phosphorus level on lettuce: P uptake, root growth and yield. Plant Soil. 263: 297-309. 2004.

11) Cook WP, Sanders DC. Nitrogen application frequency for drip-irrigated tomatoes. Hortscience. 26: 250-252. 1991.

12) 湖東朗, 大沼洋康, 角張嘉孝, Suhail AI, HAFFAR I. 灌水頻度と環境因子がアルファルファの蒸散速度, 葉温 及び生育に及ぼす影響. 日本緑化工学会誌. 15: 1219. 1990.

13）昭和 59 年 4 月 18 日付け 59 農蚕第 1943 号農林水産 省農蚕園芸局長通知. 植物に対する害に関する栽培試 験の方法. 1984.

14) Shaw RJ. Soil Salinity - Electrical Conductivity and Chloride. In: Soil analysis : an interpretation manual, eds. Sparrow LA, Peverill KI, Reuter DJ. CSIRO Pub, Collingwood. 129-146. 1999.

15) R Core Team. R: A Language and Environment for Statistical Computing. 2016.

16) Spiegel MR, Schiller J, Srinivasan RA. Probability and Statistics. McGraw-Hill, New York. 1-423. 2009.

17）清水愛, 畑瀬房次, 大塚紀夫, 田中政信. 高温期のコ マツナ養液栽培における品質向上. 九州農業研究. 64 : 173. 2002.

18）留森寿士, 遠山柾雄, 竹内芳親. ホウレンソウ栽培にお ける希釈海水の潅水効果. 日本砂丘学会誌. 43: 1518. 1996.

19）江波戸宗大, 栗原三枝. 高塩類堆肥を用いた野菜栽培 での土壤溶液組成および陽イオンバランスの経時変化 (2): コマツナ連作栽培の場合. 日本土溒肥料學雜誌. 80: 233-240. 2009.

20）安東赫, 池田英男. 根域への積極的な水分管理は露 地土耕においても作物の生育, 収量と肥料利用効率の 向上に役立つ. 園芸学研究. 8: 439-443. 2009.

21）池田英男. 植物の根の周辺の無機要素の分布と流れか らみた根域の養水分管理. 池田英男編著, 養液土耕と 液肥・培地管理. 博友社, 東京. 7-27. 2005.

22）荒木陽一. かん水時の土䁃水分吸引圧と一回のかん水 量が湿潤土層深とトマトの生育に及ぼす影響. 野菜・茶 業試験場研究報告. 125-131. 1997.

23）劉建, 辺嘉賓, 塩津文隆, Ghosh Subhash C, 豊田正 範, 楠谷彰人. 水耕栽培で塩ストレスを与えた水稲品種 の耐塩性と根系形態. 日本作物学会紀事. 77: 326332. 2008. 